\title{
and Health (ICASSETH 2019) \\ A Need to the Analysis of Teaching Materials of Mandarin Speaking Based on Quantum Approach
}

\author{
Tri Budianingsih* \\ Chinese Department \\ Al Azhar of Indonesia University \\ Jakarta, Indonesia \\ *trixiaodi@gmail.com
}

\begin{abstract}
This study aims to develop the teaching materials for speaking Mandarin language based on a quantum approach. The materials are developed based on the target needs and in line with the students' learning styles. This study analyzes the lecturer's and students' needs in the domains of learning styles, learning goals, themes/topics, learning materials, learning strategies, learning methods, learning media, and evaluation. This study employed qualitative and quantitative approaches by distributing a questionnaire to one lecturer and 19 students. The results revealed that the lecturer and students needed new teaching materials delivered by the quantum approach. The domains with the largest percentage of presentation were learning objectives $100 \%$, themes/topics $100 \%$, speaking teaching materials $95 \%$, learning media90\%, and student-centered method $63 \%$.
\end{abstract}

Keywords: needs analysis, speaking teaching materials, quantum approach

\section{INTRODUCTION}

The principles in designing the teaching materials of Mandarin speaking encompass the principle of accuracy (针对性zhēnduìxìng), usability (实用性shíyòngxìng), and attractability (趣味性qùwèixìng). In the principle of accuracy (针对性zhēnduìxing), the teaching materials are designed by taking into account the different characteristics of the teaching objectives. Jun in Quan also said that the teaching materials for Mandarin speaking must clearly focus on the learning objectives and the characteristics of teaching Mandarin language for speakers of other languages [1].

Quan said that the teaching materials for Mandarin speaking for adult's learners are targeted to be related to general goals in a variety of contexts. The materials must clearly state some elements such as students' conditions, Mandarin language skills, learning objectives, goals for using Mandarin language in the future, duration of the study, training objectives, students' ages, identity, native language, culture, social factors, learning interest, and learning habits. This is because the learners have different characteristics. Teaching materials for adult learners cannot be compared to those for young learners because if the materials for the adult learners contain more writing than pictures. Consequently, teaching young learners with adult's materials will be ineffective and vice versa. Adult learners must encounter the learning process through writing than pictures since they have to deal with abstract things more than concrete things. In addition to teaching materials, teaching methods can also affect the students' learning. An interesting method can increase their learning outcomes [1]. Quan's statement is justified by previous research conducted by Meli that developing teaching materials need to consider the difficulties encountered by the students because their native language is Indonesian language. Furthermore, Meli evaluated the development of teaching materials about phonetics in Mandarin language. This particular lesson was determined as the general problem so that it became the basis for developing the teaching materials [2]

The Quantum Learning method was coined by Dr. Georgi Lozanov who experimented about "Suggestology". This is a way using suggestion that can affect the outcome of a learning situation. The suggestion can positively or negatively affect the teaching and learning process of the students in absorbing the lessons. The technique that can be done is to provide a comfortable atmosphere, put up posters that attract the students' attention in the classroom and that show information about the materials being taught [3].

To be able to meet these needs, a needs analysis should be taken into account. According to Tomlinson, needs analysis for learning materials development has a variety of objectives in language learning, namely: 1) knowing the needs of students' language skills so that they can carry out certain roles, for example marketing managers, tour guides, and students, 2) helping in determining the accuracy of teaching materials to the needs of potential students, 3 ) selecting students in a group that really requires specific language skills training, 4) recognizing the likelihood of someone in the group, 5) recognizing the distance between what students are able to do and what they need to be able to do, and 6) gather information about students' specific problematic experiences [4].

According to Atwi, the following characteristics of students need to be considered in the instructional design process [5].

- Learning motivation, external or internal, as the basis of choosing learning strategies.

- Access to learning resources that are relevant to learning materials as the basis for determining the appropriateness of the learning materials. 
- Independent learning habits and discipline in organizing learning when assigning homework.

- Access to communication channels and information technology media for online guidance.

- Habits and the ability to learn and think about the application of materials learned in work or daily life, as the basis for designing practical examples.

- Residence if measured by distance to the place of the learning activities in designing additional learning activities.

As cited by Budianingsih, Macalister said that a needs analysis was carried out to find out what the students intend to do. In other words, it is an attempt to find out how far the students know something related to the learning to be followed and what they need. By doing a needs analysis, the developer will recognize the real conditions and knowing what things are beneficial to the students. Macalister said that the analysis needs to ensure that learning will contain things that are relevant and beneficial to students and the learning process [6].

Based on the description above, the issues to be discussed are as follows.

- What are the needs of the lecturers related to the dimensions of learning objectives, themes, materials, strategies, methods, learning media, assignments / exercises and evaluations?

- What are the needs of the students related to the dimensions of general goals, specific learning objectives, topics, materials, aspects of speaking material, strategies, methods, learning media, assignments / exercises based on the content of the material, assignments / exercises based on the number of people, types of evaluation based on the materials, the number of people, and the evaluation time?

\section{RESEARCH METHODS}

This study was designed as a descriptive analysis whose results were analyzed by simply calculating the mean scores. A questionnaire was distributed to 19 students and one lecturer. This questionnaire was formulated based on the combination of Likert scale and Guttman scale. The Likert scale represented an indicator in which the answer of each item had a graduation from very positive to very negative, which can be in the form of words or scores. Meanwhile, the Guttman scale represented a more rigid answers or nominal answers like "yes-no" questions; "True False"; "Ever-never"; "Positive-negative" and the equivalent. The following categories were the needs of the lecturers and students.

TABLE I. CATEGories NEEd ANALysis LeCtuRE AND STUdENT

\begin{tabular}{|l|l|l|}
\hline $\begin{array}{c}\text { Percentage of the average score } \\
\text { of the needs criteria (\%) }\end{array}$ & \multicolumn{1}{|c|}{ Category } & \multicolumn{1}{c|}{ Note } \\
\hline $0-25$ & Not needed & Not prioritized \\
\hline $26-50$ & Less needed & Less prioritized \\
\hline $51-75$ & Needed & Prioritized \\
\hline $76-100$ & Highly needed & Highly prioritized \\
\hline
\end{tabular}

In addition to the category of the needs analysis, there was a detailed framework of the lecturer's and students' needs as follows.

TABLE II. THE DETAILED FRAMEWORK OF THE NEEDS ANALYSIS OF THE LECTURER USING LIU XUN'S THEORY [7]

\begin{tabular}{|c|c|c|c|}
\hline NO & Dimension & Operational definition & Indicator \\
\hline 1 & Reference & $\begin{array}{l}\text { Reference used for } \\
\text { developing the materials }\end{array}$ & $\begin{array}{l}\text { Reference based on } \\
\text { the needs }\end{array}$ \\
\hline 2 & $\begin{array}{l}\text { Learning } \\
\text { objectives }\end{array}$ & $\begin{array}{l}\text { The objectives intended } \\
\text { to achieve by the } \\
\text { students in learning } \\
\text { Mandarin speaking }\end{array}$ & $\begin{array}{l}\text { Specific objectives } \\
\text { (self-confidence and } \\
\text { fluency in speaking } \\
\text { Mandarin) }\end{array}$ \\
\hline 3 & Themes/Topics & $\begin{array}{l}\text { Themes/Topics needed } \\
\text { to learn Mandarin } \\
\text { speaking for the students }\end{array}$ & Themes/Topics \\
\hline 4 & Learning materials & $\begin{array}{l}\text { Materials expected by } \\
\text { the students to obtain } \\
\text { adequate information } \\
\text { about } \\
\text { speaking }\end{array}$ & $\begin{array}{l}\text { Mandarin speaking } \\
\text { skill }\end{array}$ \\
\hline 5 & Learning strategy & $\begin{array}{l}\text { Strategies expected by } \\
\text { the students to master } \\
\text { Mandarin speaking well }\end{array}$ & $\begin{array}{l}\text { Strategy of Mandarin } \\
\text { speaking skill }\end{array}$ \\
\hline 6 & Learning method & $\begin{array}{l}\text { Methods expected by the } \\
\text { students in learning } \\
\text { Mandarin speaking }\end{array}$ & $\begin{array}{lr}\text { Methods } & \text { of } \\
\text { Mandarin } & \text { speaking } \\
\text { skill } & \end{array}$ \\
\hline 7 & Learning media & $\begin{array}{l}\text { Media expected by the } \\
\text { students in learning } \\
\text { Mandarin speaking }\end{array}$ & $\begin{array}{l}\text { Media of Mandarin } \\
\text { speaking skill }\end{array}$ \\
\hline 8 & Tasks/Exercises & $\begin{array}{l}\text { Tasks/Exercises } \\
\text { expected by the students } \\
\text { in the Mandarin course }\end{array}$ & $\begin{array}{l}\text { 1. Tasks/exercises } \\
\text { based on the } \\
\text { materials (theory, } \\
\text { practice, field task) } \\
2 \text { Tasks/exercises } \\
\text { based on the number } \\
\text { of students } \\
\text { (individual/group) }\end{array}$ \\
\hline 9 & Evaluation & $\begin{array}{l}\text { Learning evaluation } \\
\text { expected by the students } \\
\text { in learning Mandarin } \\
\text { speaking }\end{array}$ & $\begin{array}{l}\text { 1. Evaluation type } \\
\text { based on the needs. } \\
\text { 2. Evaluation type } \\
\text { based on the number } \\
\text { of students } \\
\text { 3. Evaluation time }\end{array}$ \\
\hline
\end{tabular}

TABLE III. THE DETAILED FrAMEWORK OF THE NEEDS ANALYSIS OF THE STUDENTS USING LIU XUN'S THEORY [7]

\begin{tabular}{|l|l|l|l|}
\hline No & \multicolumn{1}{|c|}{ Dimension } & \multicolumn{1}{|c|}{$\begin{array}{c}\text { Operational } \\
\text { Definition }\end{array}$} & \multicolumn{1}{|c|}{ Indicator } \\
\hline 1 & Learning objectives & $\begin{array}{l}\text { The objectives } \\
\text { intended to achieve by } \\
\text { the students in } \\
\text { learning Mandarin } \\
\text { speaking }\end{array}$ & $\begin{array}{l}\text { 1. General objective } \\
\text { (Can get work, pursue } \\
\text { further education, } \\
\text { tourism, etc) } \\
\text { 2. Specific objectives } \\
\text { (self-confidence and } \\
\text { fluency in speaking } \\
\text { Mandarin) }\end{array}$ \\
\hline
\end{tabular}


Table III. Cont.

\begin{tabular}{|l|l|l|l|}
\hline 2 & Themes/Topics & $\begin{array}{l}\text { Themes/Topics } \\
\text { needed to learn } \\
\text { Mandarin speaking } \\
\text { for the students }\end{array}$ & Themes/Topics \\
\hline 3 & Learning materials & $\begin{array}{l}\text { Materials expected by } \\
\text { the students to obtain } \\
\text { adequate information } \\
\text { about Mandarin } \\
\text { speaking }\end{array}$ & $\begin{array}{l}\text { Mandarin speaking } \\
\text { skill }\end{array}$ \\
\hline 4 & Learning strategy & $\begin{array}{l}\text { Strategies expected by } \\
\text { the students to master } \\
\text { Mandarin speaking } \\
\text { well }\end{array}$ & $\begin{array}{l}\text { Strategy of Mandarin } \\
\text { speaking skill }\end{array}$ \\
\hline 5 & Learning method & $\begin{array}{l}\text { Methods expected by } \\
\text { the students in } \\
\text { learning Mandarin } \\
\text { speaking }\end{array}$ & $\begin{array}{l}\text { Methods of Mandarin } \\
\text { speaking skill }\end{array}$ \\
\hline 6 & Learning media & $\begin{array}{l}\text { Media expected by the } \\
\text { students in learning } \\
\text { Mandarin speaking }\end{array}$ & $\begin{array}{l}\text { Media of Mandarin } \\
\text { speaking skill }\end{array}$ \\
\hline 7 & Tasks/Exercises & $\begin{array}{l}\text { Tasks/Exercises th the } \\
\text { expected by the } \\
\text { students in the } \\
\text { Mandarin course }\end{array}$ & $\begin{array}{l}\text { Tasks/exercises } \\
\text { based on the materials } \\
\text { theory, practice, field } \\
\text { task) } \\
2 . \\
\text { based on the number of } \\
\text { students } \\
\text { (individual/group) }\end{array}$ \\
\hline 8 & Evaluation & $\begin{array}{l}\text { Learning evaluation } \\
\text { expected by the } \\
\text { students in learning } \\
\text { Mandarin speaking }\end{array}$ & $\begin{array}{l}\text { Evaluation type } \\
\text { based on the needs. } \\
\text { Evaluation type } \\
\text { based on the number of } \\
\text { students } \\
\text { 3. Evaluation time }\end{array}$ \\
\hline
\end{tabular}

\section{RESULTS AND DISCUSSION}

This section aims to elaborate on the results of the data analysis process obtained from the questionnaire.

\section{A. Needs Analysis of the Lecturers}

Generally, the lecturers agreed that teaching materials should be only based on the needs of the students so that they can absorb the materials more quickly. Additionally, they would be motivated to learn. However, the materials must be balanced with the level of students' abilities in general. Therefore, the learning objectives to be achieved by the Mandarin speaking II lecturers encompassed the students 'abilities to learn quickly and speak Mandarin confidently. The lecturers reported that the students were not too confident in speaking Mandarin due to lack of vocabulary so they were afraid of being wrong and ashamed. They were expected to speak Mandarin fluently with the correct pronunciation and tone because Mandarin language has so many different tones and different pronunciation. Consequently, if it is wrongly spoken, the result will be problematic like ambiguous meaning.

Furthermore, regarding the learning topics, the lecturer stated that the materials should cover everyday topics / themes. It was aimed to get the students more familiar with the language use and to be able to absorb the materials quickly. The topics comprised: introducing self and other people, expressing hobbies / interests, asking for directions, buying and selling / bargaining, and using the telephone. The lecturer also added some other topics: food, health, weather, sightseeing, and clothing.

The lecturers also posited that the students needed to tell stories, talk or have a dialogue, make phone calls, and discuss. The aspects of Mandarin speaking materials needed by the students according to the lecturer consisted of vocabularies and grammar. Both language aspects were really needed so that the students could be more confident in speaking Mandarin. With a good repertoire of vocabulary and grammar, they could overcome their anxiety at speaking Mandarin.

With respect to the learning strategy, the lecturer argued that the students needed pronunciation, tone, and all elements of the learning strategy to increase their confidence because Mandarin has 4 (four) notes that are different from Indonesian language. They can affect the words meaning. If they could master it well, it strengthened their confidence even better. The lecturer also added that the learning strategies needed by the students were the ability to employ neutral tone and changing tone. This is important because Mandarin is a language that emphasizes tone.

Related to the learning method, the lecturer reported that a student-centered method was preferred where students become the center of attention. It could trigger the students' activeness and creativity. The lecturer only becomes the motivator and the observer, so that the learning atmosphere in the classroom is not boring. Such a circumstance will affect the manifestation of students' passion on the learning activities. Thus, the use of quantum learning method is in accordance with the teaching material models developed. The findings support previous research conducted by Yanuarty and Sobandi stating that the application of quantum teaching method can boost of the students' learning outcomes [8]. Furthermore, the lecturer asserted that some of the needed learning media were videos about the themes / topics in each meeting. An audio CD was also mentioned to support the implementation of the learning method.

The exercise materials needed by the lecturer comprised short questions, single picture, retelling, sentence completion, sentences making, and conversations. Those were needed to get the students used to practice speaking Mandarin.

Meanwhile, the types of exercises needed by the lecturer varied from individual to group exercises. It was believed that the students would be not bored with Mandarin speaking exercises. To find out the students' ability in speaking Mandarin, evaluation materials were needed. The materials were pronunciation, tone, choice of words, fluency, and grammar. They were needed so that the students could speak Chinese properly and correctly.

Regarding the time to conduct the evaluation was argued by the lecturer to be as punctuate as possible because the lecturer could recognize the students 'understanding level on the learning materials. It is in accordance with the assessment principle of quantum learning approach in which there is 
always an evaluation and celebration for the students' learning achievement at the end of each lesson. The following table depicts the detailed explanations.

TABLE IV. PORTRAIT OF THE LECTURER's NEEDS ANALYSIS

\begin{tabular}{|c|c|c|c|}
\hline No & Dimension & Indicator & Lecturer's Needs \\
\hline 1 & $\begin{array}{l}\text { Reference for } \\
\text { developing the } \\
\text { teaching } \\
\text { materials }\end{array}$ & $\begin{array}{l}\text { Reference based on } \\
\text { the needs }\end{array}$ & $\begin{array}{l}\text { Agreed that the materials } \\
\text { should be based on the } \\
\text { students' needs in order for } \\
\text { the students to be able to } \\
\text { absorb it quickly, but should } \\
\text { be suited with the students' } \\
\text { proficiency level as well. }\end{array}$ \\
\hline \multirow[t]{2}{*}{2} & \multirow[t]{2}{*}{$\begin{array}{l}\text { Learning } \\
\text { objective }\end{array}$} & \multirow[t]{2}{*}{ Specific objective } & $\begin{array}{l}\text { Argued that the students can } \\
\text { study the materials quickly } \\
\text { to become more confident } \\
\text { and more fluent in speaking } \\
\text { Mandarin }\end{array}$ \\
\hline & & & $\begin{array}{l}\text { Expected the students to be } \\
\text { able to speak Mandarin well }\end{array}$ \\
\hline 3 & Themes/Topics & $\begin{array}{l}\text { Themes/Topics } \\
\text { needed to learn } \\
\text { Mandarin speaking } \\
\text { for the students }\end{array}$ & $\begin{array}{l}\text { Daily themes/topics" } \\
\text { introducing self and other } \\
\text { people, hobbies.interests, } \\
\text { asking for direction, } \\
\text { bargaining, talking at the } \\
\text { telephone, talking about } \\
\text { food, health, weather, } \\
\text { climate, recreation, and } \\
\text { clothes. }\end{array}$ \\
\hline \multirow[t]{2}{*}{4} & \multirow{2}{*}{$\begin{array}{l}\text { Learning } \\
\text { materials }\end{array}$} & \multirow{2}{*}{$\begin{array}{l}\text { Mandarin speaking } \\
\text { skill }\end{array}$} & $\begin{array}{l}\text { Telling stories, having a } \\
\text { conversation and dialogues, } \\
\text { phoning, and discussing. }\end{array}$ \\
\hline & & & $\begin{array}{l}\text { New vocabulary and } \\
\text { grammar }\end{array}$ \\
\hline 5 & $\begin{array}{l}\text { Learning } \\
\text { strategy }\end{array}$ & $\begin{array}{l}\text { Strategy of Mandarin } \\
\text { speaking skill }\end{array}$ & $\begin{array}{l}\text { Pronunciation, tone, and } \\
\text { tone change }\end{array}$ \\
\hline 6 & $\begin{array}{l}\text { Learning } \\
\text { method }\end{array}$ & $\begin{array}{l}\text { Learning method of } \\
\text { Mandarin } \\
\text { skill }\end{array}$ & $\begin{array}{l}\text { Student-centered approach } \\
\text { (discussion, group work, } \\
\text { demonstration) }\end{array}$ \\
\hline 7 & Learning media & $\begin{array}{l}\text { Learning } \\
\text { Mandarin } \\
\text { skill }\end{array}$ & Videos and audio CDs \\
\hline \multirow[t]{2}{*}{8} & \multirow[t]{2}{*}{ Tasks/Exercises } & $\begin{array}{l}\text { Tasks/Exercises } \\
\text { based on the learning } \\
\text { contents (theories, } \\
\text { practices, and field } \\
\text { works) }\end{array}$ & $\begin{array}{l}\text { Question and answer, single } \\
\text { picture, retelling, sentence } \\
\text { completion, sentence } \\
\text { making, conversation }\end{array}$ \\
\hline & & $\begin{array}{l}\text { Tasks/Exercises } \\
\text { based on the number } \\
\text { of students } \\
\text { (individual/group) }\end{array}$ & $\begin{array}{l}\text { Variations between } \\
\text { individual and group works }\end{array}$ \\
\hline \multirow[t]{3}{*}{9} & \multirow{3}{*}{ Evaluation } & $\begin{array}{l}\text { Types of evaluation } \\
\text { based on the } \\
\text { materials }\end{array}$ & $\begin{array}{l}\text { Pronunciation, tone, word } \\
\text { choice, fluency, grammar }\end{array}$ \\
\hline & & $\begin{array}{l}\text { Types of evaluation } \\
\text { based on the number } \\
\text { of students }\end{array}$ & $\begin{array}{l}\text { Variations } \begin{array}{r}\text { between } \\
\text { individual and group } \\
\text { assessments }\end{array} \\
\end{array}$ \\
\hline & & Evaluation time & $\begin{array}{l}\text { Evaluation at the end of } \\
\text { each unit }\end{array}$ \\
\hline
\end{tabular}

The findings corroborate Anggraeny's study that the students' needs of learning materials can be understood by needs analysis through administering a questionnaire from the researcher. Additionally, the quality of the teaching materials can also be developed and reviewed from the content feasibility aspect, language aspect, visual aspect, delivery aspect, and graphic aspect [9].

\section{B. The Needs Analysis of the Students}

The analysis of students' characteristics is needed to know their learning styles, background, motivation, and other contributing factors in learning Mandarin language as in the research conducted by Elis. The results demonstrated that the students' learning characteristics in the economics class of XI IPS are a combination of learning styles. The tendency of the students' learning styles is also diverse [10]. In this research, the researcher viewed the students' characteristics from their general and specific objectives or motives in learning Mandarin language.

The results of the questionnaire analysis of the students' needs demonstrated several points. Generally, the students also preferred everyday life topics. However, their preferred topics were not matched with their abilities. They were found to be more interested in topics about applying for work, discussing messages and morals, and job interviews. Even though the lecturer strongly agreed that the learning materials should be based on the students' needs, they must be suited with the level of proficiency of the students. This is indeed very much in accordance with the diagram below.

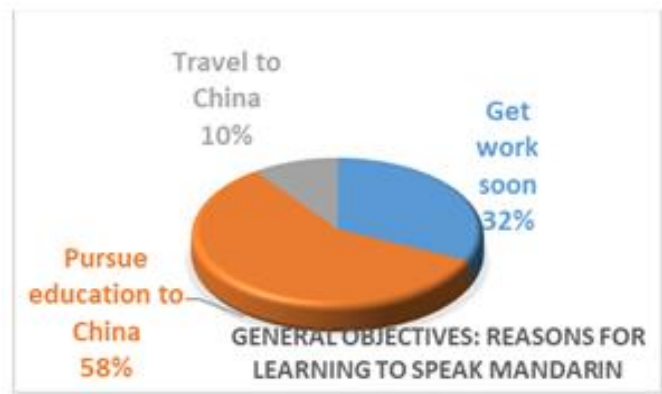

Fig. 1. Diagram of general objectives, reasons for learning speak Mandarin.

Because as many as $79 \%$ of the students have never learned to speak Mandarin before and only $21 \%$ have learned to speak Mandarin when they were at the senior high school level, it would be better for the students to start from simple topics considering the majority of their proficiency levels, so that they could absorb the materials well.

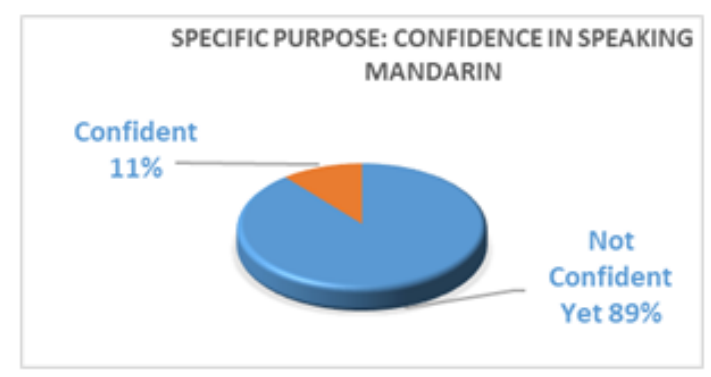

Fig. 2. Diagram of confidency in speaking Mandarin. 
The above diagram exhibits the personal objectives of the students in enrolling this course. It can be seen that they aimed to increase their level of confidence in speaking Mandarin. Additionally, all students really needed to speak Mandarin with everyday topics. The following is the detailed topics needed by the students.

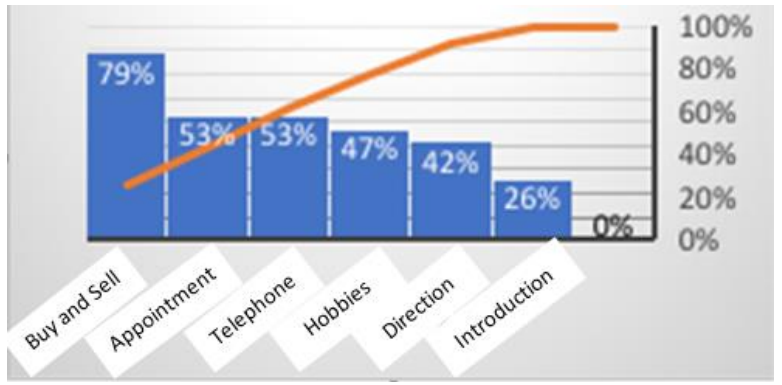

Fig. 3. Detailed topics needed by students.

The learning materials can be seen as follows.

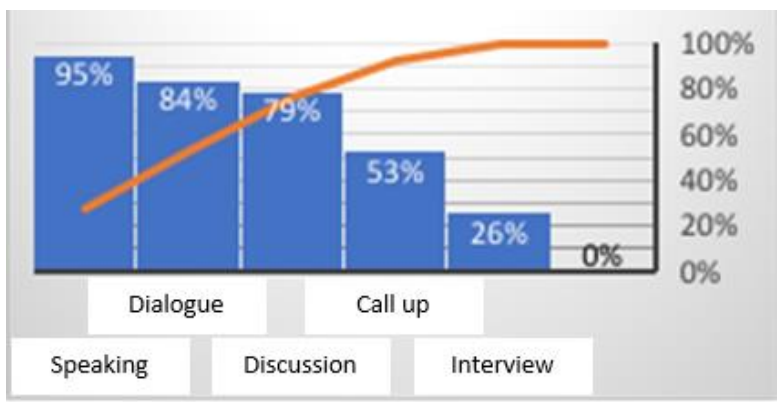

Fig. 4. Learning materials needed by students.

Related to the speaking aspects, as much as $51 \%$ of the students preferred new aspects of speaking and vocabulary as well as $49 \%$ of them also preferred grammar.

It can be concluded that the speaking material that the students preferred consisted of 3 (three) speaking skills: storytelling, conversation / dialogue, and discussion. All of these speaking skills will be adjusted to their levels and abilities. Whereas, the speaking aspects that the students preferred were new vocabulary and grammar.

In Aini's research, learning strategy can influence the students' learning outcomes. It was justified by her research entitled "Pengaruh Strategi Pembelajaran, Gaya Belajar, Sarana Praktik, dan Media Terhadap Hasil Belajar Patiseri SMK Se-Gerbangkertasusila" (The influence of learning strategy, learning style, learning facilities, and media on the learning outcomes of vocational high school students Patisserie, Gerbangkertasusila). One of the findings underscored the significantly positive effect of learning strategy on the students' learning outcomes [11].

The preferred learning strategy among the students can be seen as follows.

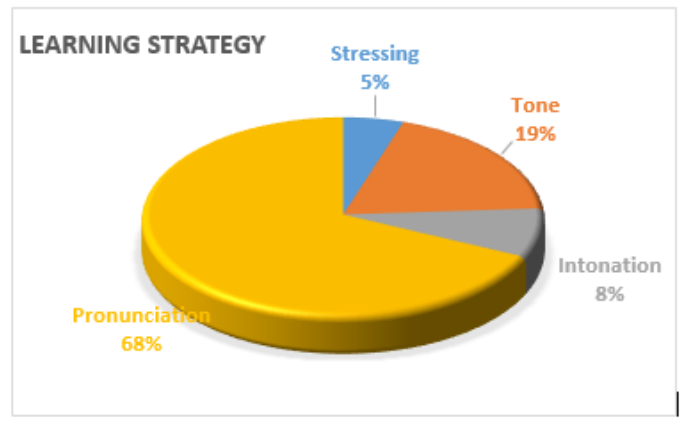

Fig. 5. Learning strategy.

Regarding the learning method, $63 \%$ of the students also preferred a student-centered learning and 37\% preferred a teacher-centered learning.

It can be concluded that the learning strategy that the students needed was pronunciation. Meanwhile, the studentcentered learning was more preferred as in accordance with the quantum learning approach. The findings are strengthened by a research conducted by Supriadi stating that pronunciation errors in Mandarin language occurred because the consonant sounds were not aspirated and the articulation place of the sounds was not in the 'post alveolar' and pronounced by 'frontal anterior'. Therefore, it affected the word meaning in the sentence [12]. Moreover, Mulyaningsih in her research also reported that the mispronunciation in terms of intonation can influence the meaning as well. That is why pronunciation is an essential aspect to learn [13].

With respect to the learning media, $90 \%$ of the students also needed videos and $10 \%$ of them were more concerned with the use of audio CDs. Therefore, it can be concluded that the majority of the students needed videos as the learning resources in developing their Mandarin speaking skills.

Furthermore, there were $84 \%$ students who preferred conversations as the exercise materials. $53 \%$ of them were concerned with sentence completion. $95 \%$ preferred question and answer exercises. $79 \%$ needed single images. $47 \%$ preferred series of images, and $84 \%$ were concerned with retelling. Meanwhile, $79 \%$ of the students preferred various types of exercises from individual to group tasks. Only 10\% needed group exercise and $11 \%$ needed individual exercise.

It can be concluded that the students preferred 5 (five) types of exercise / assignment: question and answer, single picture, retelling, sentence completion, and conversation. Meanwhile, the students preferred a variation in terms of the mode of the exercise practices: individual and group, so that they will not feel bored. The findings are in line with Jazeri's study concerning the contextual communicative learning model for international students. The findings showed that in developing teaching materials, the dialogue themes were related to dailylife communications so that the students can use Indonesian language contextually [14].

Reading the evaluation process, $89 \%$ of the students were concerned with the assessment of intonation, tone, and stressing; 68\% general pronunciation; 95\% fluency; $53 \%$ grammar; $63 \%$-word selection; and $42 \%$ expressions. This 
evaluation aspect was based on the theory of students' needs. Meanwhile, in terms of the evaluation mode, $84 \%$ of the students preferred various modes including individual and group assessments; $6 \%$ individual evaluation; and 10\% group evaluation.

It can be concluded that the majority of the students preferred 4 (four) evaluation contents: pronunciation, word choice, fluency, and grammar. Additionally, they needed variations in terms of the evaluation mode ranging from individual to group assessments, so that the assessments are expected to be able to cater the students' various abilities.

Last but not least is the students' preferences on the time of participating in the evaluation process. $10 \%$ of the students preferred at the very last part of the course after all units were delivered; $74 \%$ at the end of each unit; and $16 \%$ after two or more units. Therefore, it can be concluded that the students were more concerned with the evaluation process at the end of each unit.

\section{CONCLUSION}

Based on the results of the lecturer's and students' needs analysis, this study has demonstrated that the needs between the lecturer and the students are slightly different, especially on the preferred themes or topics. It is because the students report that after graduating, they want to get a job quickly and want to continue their studies. Therefore, the themes/topics they need most are about applying for jobs, conducting interviews, and the like. However, due to the mismatch between the expectations and the reality of their proficiency level, those topics will be given in the upper-level semesters. Additionally, the students also choose themes in accordance with their daily needs, such as buying goods, discussing hobbies and health, and the like. $98 \%$ of the UAI level 1 students are not of Chinese descent, but they have a high desire to be able to speak Mandarin confidently.

\section{ACKNOWLEDGMENT}

The researchers would like to express many thanks to the Research and Community Services Body (LP2M) Universitas Al Azhar Indonesia (UAI) who has funded this research.

\section{REFERENCES}

[1] L. Quan, 对外汉语教育研究 Duiwai Hanyu Jiaoyu Yanjiu. Beijing: Shangwu Yinshuguan, 2009.

[2] Meli, "Evaluasi Penyusunan Materi Pengajaran Fonetik Bahan Ajar Bahasa Mandarin,” Jurnal pendidikan bahasa\&sastra, vol. 15, no 2, pp. 199-212, 2015.

[3] B. DePoter and Hernacki, Quantum Learning: Membiasakan Belajar Nyaman dan Menyenangkan. Bandung: Kaifa, 2016.

[4] B. Tomlinson, "Materials Development for Language Learning and Teaching," Language Teaching, vol. 45, no. 2, pp 143-179, 2012.

[5] A. Suparman, Desain Instruksional Modern. Jakarta: Erlangga, 2012.

[6] T. Budianingsih, "Quantum-Based Approach For Learning Spoken Mandarin: A Model Of Teaching Material," journal of Education Teaching and Learning, vol. 3, no. 1, pp. 159-165, 2018.

[7] L. Xun, 对外汉语教育学引论 Duiwai Hanyu Jiaoyu Xueyinlun. Beijing: Beijing Language and Culture University Press, 2010

[8] A. Yanuarti and A. Sobandi, "Upaya Meningkatkan Hasil Belajar Siswa Melalui Penerapan Model Pembelajaran Quantum Teaching," Jurnal Pendidikan Manajemen Perkantoran, vol. 1, no. 1, pp. 11-18, 2016.

[9] D.A.I. Mustafa and A. Efendi, "Pengembangan bahan ajar pembelajaran menulis cerita berbasis pendekatan proses bagi siswa SMP," LingTera, vol. 3, no. 1, pp. 1-8, 2016.

[10] E. Elis, M. Ulfah and A. Achmadi, "Analisis Karakteristik Gaya Belajar Siswa pada Mata Pelajaran Ekonomi Kelas XI IPS,” Jurnal Pendidikan dan Pembelajaran Untan, vol. 6, no. 1, 2017.

[11] S.N. Aini and P. Sudira, "Pengaruh Strategi Pembelajaran, Gaya Belajar, Sarana Praktik, Dan Media Terhadap Hasil Belajar Patiseri SMK SeGerbangkertasusila," jurnal pendidikan vokasi, vol. 5, no. 1, pp. 88-102, 2015 .

[12] N. Supriadi, "Analisis Kesalahan Fonologis Bahasa Mandarin Oleh Mahasiswa D3 Bahasa Mandarin Universitas Jendral Soedirman,” Jurnal parole, vol. 4, no. 2, pp. 99-119, 2014.

[13] D.W. Mulyaningsih, "Perbandingan Fonologi Bahasa Indonesia Dan Bahasa Mandarin," jurnal pendidikan bahasa dan sastra, vol. 13, no. 1, pp. 1-10, 2014.

[14] M. Jazeri, "Model Perangkat Pembelajaran Keterampilan Berbicara Dengan Pendekatan Komunikatif Kontekstual Bagi Mahasiswa Asing," jurnal litera, vol. 15, no. 2, pp. 217-226, 2016. 